\title{
Teachers' Perceptions of using Gamification Apps in Teaching Speaking Skill to EFL Young Learners
}

\author{
Nguyen Thi Thanh Thuy ${ }^{1}$, Luu Nguyen Quoc Hung ${ }^{2}$ \\ ${ }^{1}$ Bachelor, School of Foreign Languages, Can Tho University, Vietnam \\ ${ }^{2}$ Doctor, School of Foreign Languages, Can Tho University, Vietnam
}

\begin{abstract}
Gamification is a concept that is commonly used in sectors such as education, information studies, humancomputer interaction, and health. Recently, gamification apps have been widely used in teaching English in order to increase learners' interests, engagement and joyfulness. In addition, there have been plenty of prior studies about the effectiveness of gamification in English education but there seemed to be little research about the correlation between gamification and teaching speaking skills. As a result of this, the current study investigated teachers' perspectives on the benefits and challenges of using gamification in teaching speaking skills to young learners. The study enlisted the help of 69 teachers. To explore teachers' perceptions of gamifying apps, a questionnaire and a semi-structured interview were administered. The findings indicated that gamifying applications benefited teaching speaking to young learners in 4 stages: raising awareness, appropriation, autonomy and giving feedback. Still, there were some challenges involving external factors and teacher-related factors that must be considered and overcome when using gamification applications.
\end{abstract}

Keywords - gamification apps, speaking skill, young learners.

\section{Introduction}

In today's modern world, software- based teaching has gradually gained a prominent place in English education due to the advent of technology. One of the prime instances for this improvement is using gamification apps in teaching English for young learners. Martí-Parreño, Méndez-Ibáñez† and Alonso-Arroyo (2016) stated in their study that games have a potential effect on motivating students and making them more engaged in their studies. More importantly, not only does it activate students' motivation but it also contributes to the academic results (Yildirim, 2017). As a result of this, there is more and more the presence of gamification apps in English teaching and learning.

Regarding English education in Viet Nam setting and specifically in Can Tho city, English has never failed to draw the attention of educators, learners and parents' learners. The main reason is that "language proficiency is a core skill required to meet internationalisation requirements" Baldauf (2012). Learning language becomes a key to open many opportunities in life. However, teaching and learning English has remained limited. One of them is too much focusing on teaching and learning grammar but ignore the importance of communication. As a result, learners tend to lose fluency in oral performance and become afraid of speaking English. Moreover, the pressure of grades make them feel increasingly bored and even hate learning English. Consequently, it is crucial to employ interesting methods and gradually shift to emphasize the importance of fluency and speaking skill. Incorporation of innovative technology is necessary to motivate learners as well as enhance their learning outcome. Gamification apps are up-to-date tools that can aid teachers and students in English education. More importantly, it has value in engaging learners and improving their learning attitude.To discover teachers' thorough understanding and perception of using gamification apps in teaching EFL young learners, specifically in speaking skills, this study was conducted with 2 research questions:

1/What are teachers' perceptions of the benefits of gamification apps in teaching speaking skill to EFL young learners? 
DOI: $\underline{10.51386 / 25815946 / \mathrm{ijsms}-\mathrm{v} 4 \mathrm{i} 5 \mathrm{p} 108}$

Volume: 4 Issue: 5

September to October 2021

https://www.ijssmsjournal.org

2/What are teachers' perceptions of the challenges of gamification apps in teaching speaking skill to EFL young learners?

\subsection{Gamification}

\subsubsection{Definitions of Gamification}

According to Deterding et al. (2011) and Werbach \& Hunter (2012), gamification can be defined as "the use of game design elements in non-game contexts". Specifically, gamification will apply individual elements of video games such as awards, badges, leaderboard, immediate feedbacks and so on to pedagogy. These appear to be key characteristics of gamification that distinguish it from other types of games. Gamification is a technology that tries to manipulate user behavior by activates individual motives through game plan element (Petkov et al. 2011 , p. 2). Furthermore, another purpose of gamification is to make participants more motivated, engaged and excited in their work. When it comes to education, it is said that "gamification develops learners' metacognitive abilities, promotes empathy, and builds teamwork skills (Tan Ai Lin et al., 2018).

\subsubsection{Differences between gamification and serious games}

In English classrooms, many practitioners have generated the distinction between gamification and serious games as well as employed them with different processes. According to Landers (2014), although serious games and gamification design share the purpose of enhancing learning outcome, they are different in the way to gain this objective. Gamification incorporates elements of games into pedagogy to motivate students to higher and more meaningful levels of engagement. In another word, gamification has an indirect influence on learning through changing behavior and attitude. In terms of serious games, they are intended for training, stimulation, and education in virtual environments with predefined learning objectives. Serious games were initially designed to train people for certain duties, such as training army personnel. Serious gaming is seen in the educational setting as a particularly active, problem-solving, contextual, and social style of learning with immediate and differentiated feedback that also encourages the enjoyment of learning (Garris et al., 2002; Iten \& Petko, 2016; Tobias et al., 2011).

\subsubsection{The use of gamification apps in teaching speaking skill for young learners}

In the first stage of the speaking lesson, it is essential to get young learners to feel more engaged and know about the objectives of the lesson. The gamification apps can also be used to catch learners' attention or interests. Teachers and students can access the apps through computers, laptops, tablets or smartphones. Furthermore, gamification apps are employed into activities in a speaking classroom such as providing inputs (vocabulary, grammar, discourse markers,...). Burns indicated that it is important to introduce "activities that are integrated and sequenced and that allow students to raise their awareness of the knowledge, skills and strategies needed for various types of interaction and discourse" (2012). In the following stage, learners have opportunities to be involved in practice control. The apps can aid learners to consolidate the language through the designed activities from the teacher. In the step of conducting speaking performance, teachers flexibly combine methods and activities to have students produce language with self- regulation and limit interventions. With the help of gamification apps, teachers can ask students to record their presentation or talks on online platforms and leave the feedback there. Beside, according to Landers (2014), gamification of learning was defined as "the use of game elements, including action language, assessment, conflict/challenge, control, environment game fiction, human interaction, immersion, and rules/goals, to facilitate learning and related outcomes" (p. 757). Games elements are employed effectively into classroom activities. These elements can help to create a stimulating environment and motivation for students. As gamification tools are used, game elements are responsible for supporting learning motivation and managing learners' speaking practice to improve their fluency.

- Badges: Trophies that appear as icons or logos on a webpage that signify a user's accomplishments of a particular activity such as completion of a project

- Reward structures:Some of these structures are: Points which are obtained when students complete particular tasks, badges given as the students overcome a certain level or gain achievements.

- Avatars: They are one of the features of video games. It represents user' character. Using this to teach young learners can catch their interest because children tend to enjoy animated images like that.

- Leaderboards: Learners can track their progress by checking the top "players" who have performed well. It is a way to increase a sense of competition and motivation. The more competitive and 


\section{DOI: $\underline{10.51386 / 25815946 / \mathrm{ijsms}-\mathrm{v} 4 \mathrm{i} 5 \mathrm{p} 108}$}

Volume: 4 Issue: 5

September to October 2021

https://www.ijsmsjournal.org

challenging they find, the more practice they do. As a result, they can achieve fluency in speaking English. (Bunchball, 2010 \& Educause, 2011).

On the whole, gamification tools can be used flexibly as an activity in the classroom to give students an opportunity to perform speeches or self-study activity at home to extend their learning time. Moreover, it is essential to inform learners of the way to use the tools, and attract them with game elements systems before asking them to use these tools.

\subsection{Teaching speaking skill}

\subsubsection{The components of speaking}

In the present study, the researcher relies on the theory of Brown (2004) about the key elements of speaking. They are vocabulary, grammar, fluency, and pronunciation.

\section{Vocabulary}

Vocabulary is still an important indicator of proficiency in language acquisition, so students work hard to improve it. According to Bohari, (2020) vocabulary "is a total number of words, which make up a language". Nagy et al. (2000) also shared the same ideas about vocabulary that 'vocabulary' indicated words that are learned by memorizing short definitions, and sentences are understood in a bottom-up way by piecing together the meanings of individual words.

\section{Grammar}

Grammar is often understood as the language rules in spoken language and written language. It has an influence on speaking or writing accuracy. Therefore, most teachers try to teach students the rules and provide them with a lot of grammatical practice. However, as stated by Larsen- Freeman (2001) grammar is about much more than form, and kids are harmed when they are merely given rules. As a result, most teachers embrace a more communicatively oriented approach to teach grammar effectively. Nunan (1998) also asserted that "unless they give opportunity for learner to explore grammatical structure in context, they make the task of developed technical skill”.

\section{Fluency}

Fluency, according to Hedge (2000), is the ability to answer coherently by piecing words and phrases together, pronouncing sounds clearly, and using stress and intonation. Fluency is one of the characteristics of speaking abilities, meaning a continuous stream of communication by overcoming all linguistic barriers in order to communicate a message. As a result, fluency signals imply that the speakers are communicating without having to worry about the language components. As a result, in order to be fluent in the language, the speaker needs speak fast and with little delays (Lackman, 2010).

\section{Pronunciation}

The term "pronounciation" refers to the way sounds are employed in communication (Goh and Burns, 2012). Pronunciation is the most difficult component of speaking, whether you are a natural speaker or not. Every time a learner wishes to improve his or her pronunciation, he or she must practice the vocabulary. The students must be aware of the various sounds, as well as where the words should be stressed and when to utilize rising and low intonation. These factors help pupils' ability to communicate successfully.

\subsubsection{Activities in teaching English speaking skill}

Goh \& Burns (2012) suggested a teaching- speaking cycle which referred to key concepts from which proper speaking activities can be designed. 


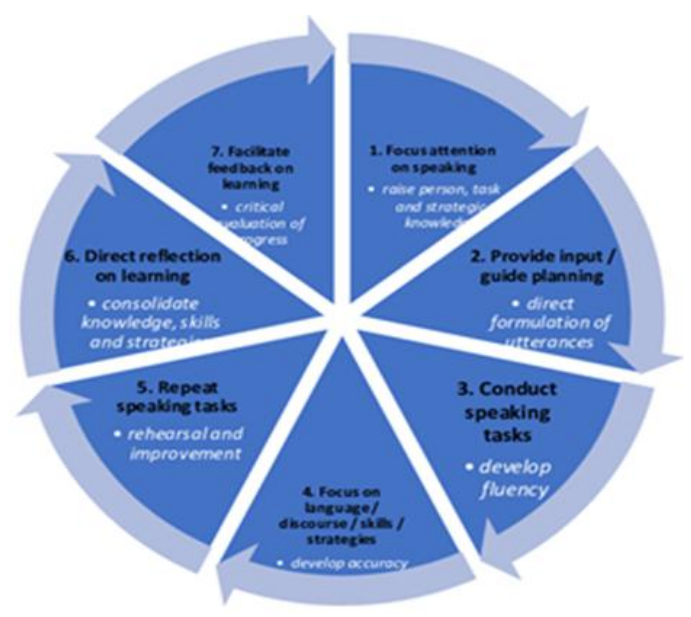

Fig. 1 Teaching- speaking cycle (Goh \& Burn, 2012)

Thornbury (2005) developed three stages to teaching speaking, known as Discovery approach, including Awareness raising (other-regulated - assisted/scaffolded), Appropriation (other-regulated - assisted/scaffolded) and Automaticity (self-regulated - unassisted). He explained that during the awareness-raising stage, learners receive new knowledge and become acquainted with it; during the appropriation stage, the newly received knowledge is integrated into the existing repertoire; and during the autonomy stage, the knowledge is used in real-life situations without the assistance of others.

\section{Awareness raising}

Thornbury (2005) indicated some degree of conscious awareness including attention, noticing and understanding. In this stage, there are some basic activities:

- Activate background knowledge: establishing the context or topic of speech events; brainstorming vocabulary related to the topic; providing words that students cannot come up with.

- Check gist: play an extract and general questions; use video materials to provide contextual information; repeating listenings to have learners note key words.

- Check details: using listening comprehension along with tasks such as table completion, filling the grid, multiple choice questions.

- Check register: particularizing the tenor of the speech situation, clarifying the relationship between speakers and social distance.

\section{Appropriation}

Thornbury considered the term "appropriation" as practiced control instead of controlled practice (2005). It can be seen that this concept was a bit different from the PPP approach which mentioned 3 teaching stages: Presentation, Practice (controlled practice and freer practice) and Production. He indicated that controlled practice tended to be a repetitive activity of language items which seemed to reduce possible mistakes. On the other hand, practiced control permitted more mistakes and was always supported by the teachers. Some suggested activities in this stage are drilling, chants, memorizing scripts, task repetition, writing, reading aloud, and communicative tasks.

\section{Autonomy}

There are many theories about autonomous learning. As stated by Ramirez (2015), autonomy is a set of skills that enables students to take more responsibility for their learning. It is said that autonomous learners are 
DOI: $\underline{10.51386 / 25815946 / \mathrm{ijsms}-\mathrm{v} 4 \mathrm{i} 5 \mathrm{p} 108}$

"intrinsically motivated, perceive themselves to be in control of their decision-making, take responsibility for the outcomes of their actions and have confidence in themselves" (Deci \& Ryan, Bandura, and Doyal \& Gough, as cited in Ceylan, 2015, p. 86). According to Thornbury, autonomy is the capacity of self- regulating performance, self-confidence, and being incentive to take risks. He also asserted that "autonomy was partly an increased automaticity of language production." Regarding criteria of speaking tasks, he mentioned some factors:

- $\quad$ Productivity: To allow for autonomous language use, speaking activities must be as productive as possible.

- Purposefulness: Speaking activity needs to have a clear outcome in order to increase language productivity.

- Interactivity: Learners should take into account their interaction with their interlocutors in conversations or audiences in presentations.

- Challenge: Tasks should have a proper difficulty level to give learners a sense of accomplishment and excitement.

- Safety: Students may feel confident and secure because of no judgemental attitude to errors from their teacher in addition to reasonable support.

Authenticity: Speaking tasks should have some relation to real- life language use.Besides, Thornbury also suggested some possible activities for this stage such as presentation and talks, tape diaries, human- computer interaction (using automatic speech recognition software)...

\section{Feedback for speaking}

Thornbury did not insert feedback or assessment into the main stage of his theory, but he mentioned in a seperate section in his book. He signified that giving feedback improperly while learners were performing their speeches could minimize their autonomy. Teachers' feedback should assist self- regulation and self- assessment of students. This was also supported by the study of Elçin \& Öztürk (2016) that learners expected teachers' feedback after the completion of their talks so as not to interrupt and demotivate them. Thornbury also approved that keeping a record of errors was a thing teachers needed to do. An immediate feedback sometimes is necessary when students' message is given illogically. However, teachers should be clever to give a repair under interactive feedback not a correction.

\subsection{Young learners}

\subsubsection{Definitions}

"Young learner" was specified with many different age spans. The term "Young learners" was defined as a person below the age of 18 according to the United Nations Convention on the Rights of the Child (1990). It could also be children between the ages of about 5 years old to 12 years old (Rixon, 1999). It was acceptable to mention young children as ones attending primary school. However, educational systems vary among countries. Therefore, the starting age and ending age in this range may also be changed. It is impossible to categorize groups of children based on their maturity. The reason behind this is that the maturity can be affected by parents, culture, sex and environment. Pinter (2006) suggested a large chronological age span from 3 to 15 years old.

\subsubsection{Teaching language to young learners}

According to Cameron (2003), young learners' characteristics are different from those of older learners. Therefore, it is essential to learn about young learners' characteristics when they learn any English skills because their behaviors, emotions and cognitive development may affect their learning process. Brewster et al. (2011, pp. 27-28) pointed out that children "have lots of physical energy, have wide range of emotional needs, are developing conceptually, learn more slowly and forget things quickly, tend to be self-oriented and preoccupied with their own world, get bored easily, are excellent mimics, can be easily distracted but also very enthusiastic." They can comprehend meaningful messages but cannot yet analyze language as a system (Arıkan $\&$ Taraf, 2010). As a result, it is critical to present and use the language in meaningful contexts that reflect authentic language use (Cameron, 2001; Halliwell, 1992). Arikan's (2009, p. 90) it is supposed that the teacher can contextualize the lesson in a variety of ways, including (but not limited to) using audio or visual materials, 
DOI: $\underline{10.51386 / 25815946 / \mathrm{ijsms}-\mathrm{v} 4 \mathrm{i} 5 \mathrm{p} 108}$

Volume: 4 Issue: 5

September to October 2021

https://www.ijssmsjournal.org

incorporating realia and props, storytelling, problem solving, giving examples, demonstrating grammar usage, playing games, and teaching explicitly or implicitly. Especially at this age, children prefer to play games or watch lively learning sources and that helps them acquire the language more easily. Another trait is that young learners fancy fantasy and imagination (Pinter, 2006). Hence, the researcher believed that gamifying apps had the ability to get young learners more energetic, excited and imaginative.

\subsection{Research questions}

\section{Research Methodology}

The main aim of this research is to investigate the perceptions of teachers towards using gamification apps when teaching speaking skill to EFL young learners. Specifically, this study was to explore the merits and demerits. Besides, the study also helps to find out the particular reasons for utilizing gamification apps in teaching practices. Therefore, the study is conducted to answer the following questions:

1. What are teachers' perceptions of the benefits of using gamification apps to teach young learners English speaking skills?

2. What are teachers' perceptions of the challenges teachers face when they use gamification apps in order to teach young learners English speaking skill?

\subsection{Research design}

In the present study, a quantitative method deploying questionnaires was used to explore teachers' perceptions of the use of gamification apps to teach young learners in speaking lessons. In particular, the one-to-five Likert scale which presents different levels as strongly disagree, disagree, neutral, agree and strongly agree, was stated in the questionnaire in order to collect research results in detail. Meanwhile, for qualitative methods, interviews are intended to employ to find more insightful ideas and thoughts from participants through individual conversations.

\subsection{Participants}

The participants of this study consisted of 69 teachers who are selected from four different language centers in Can Tho city. They are teaching English online to learners ranging from primary school to adult learners who have already worked. The most important thing is that they are all teaching young learners, which are prime subjects for this research. They participated in workshops about the implementation of technology into education as well as teachers' communities in social media where they often shared about innovative and technical didactic sources such as tools, documents, games, etc.

\subsection{Research instruments}

With the aim of exploring teachers' perceptions of using gamification apps in teaching speaking skills to young learners, a questionnaire was employed in this study. In the current study, the items in the questionnaire were designed based on theory presented in Chapter 2. The structure of the questionnaire consisted of two sections: Section 1 was to ask participants to provide their demographic information while section 2 was the main part composed of 37 close-ended questions. Particularly, 37 items in section 2 in this paper were designed with Likert scale (1932) rating on fivepoint categories (Table 3.2), namely (1) strongly disagree, (2) disagree, (3) neutral, (4) agree and (5) strongly agree.

To discover deeply how teachers think of teaching speaking skill by gamification apps for young learners, a semi- structured interview was deployed. Alongside with the results from responded questionnaires, interviews are useful in collecting deeper and more thorough information that is inaccessible by questionnaires. Interview is an effective method to "ask follow-up questions to understand the reasons behind particular events." (Gay et al. 2012). In the interview for this study, there are 3 sections respectively investigating teachers' perceptions towards gamification apps, the 


\section{DOI: $\underline{10.51386 / 25815946 / \mathrm{ijsms}-\mathrm{v} 4 \mathrm{i} 5 \mathrm{p} 108}$}

benefits and challenges of utilizing these types of apps and recommendations of the teachers to use gamification apps effectively.

\section{FINDING AND DISCUSSION}

4.1 Teachers' perceptions of the benefits of using gamification apps to teach speaking skill to EFL young learners

\subsubsection{Teachers' perceptions of the benefits gamification apps in awareness-raising stage}

In order to investigate teachers' perceptions about the benefits of gamification apps in raising awareness, Descriptive statistics and Frequencies tests were run. The mean scores of all items in raising awareness were presented in Table 4.3 below.

Table I

MEAN SCORES OF ALL ITEMS IN AWARENESS- RAISING STAGE

\begin{tabular}{|c|c|c|c|c|c|c|c|}
\hline & & & & & Scale & & \\
\hline & & & 1 & 2 & 3 & 4 & 5 \\
\hline $\begin{array}{l}\text { 1. I believe gamification apps can draw young learners' } \\
\text { attention in the speaking lessons. }\end{array}$ & 4.35 & .855 & $\begin{array}{l}2 \\
(2.9 \%)\end{array}$ & & $\begin{array}{l}5 \\
(7.2 \%)\end{array}$ & $\begin{array}{c}27 \\
(39.1 \%)\end{array}$ & $\begin{array}{c}35 \\
(50.7 \%)\end{array}$ \\
\hline $\begin{array}{l}\text { 7. When young learners use gamification apps, I believe } \\
\text { they are more active and engaged in the speaking lessons. }\end{array}$ & 4.22 & .764 & & $\begin{array}{c}2 \\
(2.9 \%)\end{array}$ & $\begin{array}{c}8 \\
(11.6 \%)\end{array}$ & $\begin{array}{c}32 \\
(46.4 \%)\end{array}$ & $\begin{array}{c}27 \\
(39.1 \%)\end{array}$ \\
\hline $\begin{array}{l}\text { 12. I believe gamification apps can help me to check } \\
\text { learners' background knowledge. }\end{array}$ & 3.81 & .912 & $\begin{array}{c}1 \\
(1.4 \%)\end{array}$ & $\begin{array}{l}3 \\
(4.3 \%)\end{array}$ & $\begin{array}{c}21 \\
(30.4 \%)\end{array}$ & $\begin{array}{c}27 \\
(39.1 \%)\end{array}$ & $\begin{array}{c}17 \\
(24.6 \%)\end{array}$ \\
\hline $\begin{array}{l}\text { 19. I believe using gamification apps to present new words } \\
\text { and grammatical structures helps young learners understand } \\
\text { them easily. }\end{array}$ & 4.07 & .754 & & $\begin{array}{c}1 \\
(1.4 \%)\end{array}$ & $\begin{array}{c}14 \\
(20.3 \%)\end{array}$ & $\begin{array}{c}33 \\
(47.8 \%)\end{array}$ & $\begin{array}{c}21 \\
(30.4 \%)\end{array}$ \\
\hline $\begin{array}{l}\text { 25.I believe gamification apps can help me to introduce the } \\
\text { speaking topic. }\end{array}$ & 4.07 & .773 & $\begin{array}{c}1 \\
(1.4 \%)\end{array}$ & $\begin{array}{l}2 \\
(2.9 \%)\end{array}$ & $\begin{array}{c}6 \\
(8.7 \%)\end{array}$ & $\begin{array}{c}42 \\
(60.9 \%)\end{array}$ & $\begin{array}{c}18 \\
(26.1 \%)\end{array}$ \\
\hline $\begin{array}{l}\text { 31. I believe I can use gamification apps to help young } \\
\text { learners get familiar with the pronunciation of new words. }\end{array}$ & 4.03 & .804 & & $\begin{array}{c}2 \\
(2.9 \%)\end{array}$ & $\begin{array}{c}15 \\
(21.7 \%)\end{array}$ & $\begin{array}{c}31 \\
(44.9 \%)\end{array}$ & $\begin{array}{c}21 \\
(30.4 \%)\end{array}$ \\
\hline $\begin{array}{l}\text { 33. I believe gamification apps can provide lively video to } \\
\text { help my learners understand the contexts and functions of } \\
\text { language. }\end{array}$ & 4.23 & .825 & & $\begin{array}{c}2 \\
(2.9 \%)\end{array}$ & $\begin{array}{c}11 \\
(15.9 \%)\end{array}$ & $\begin{array}{c}25 \\
(36.2 \%)\end{array}$ & $\begin{array}{c}31 \\
(44.9 \%)\end{array}$ \\
\hline Total mean & 4.11 & & & & & & \\
\hline
\end{tabular}

As can be seen from Table I, the mean scores of 7 items ranged between 3.81 and 4.35. The agreement of teachers on the benefits of gamification apps in raising students' awareness was from high to strongly high. Specifically, item 1 received the highest agreement from the teachers $(\mathrm{M}=4.35)$. Approximately 89.8\% (39.1\% agree and $50.7 \%$ strongly agree) of participants suggested gamification apps could draw young learners' attention and make them stay focused on the speaking lesson, whereas only $2.9 \%$ participants strongly disagreed with the ability of gamification apps in catching students' attention. Besides, around $46.6 \%$ of teachers believed that their students were more active and engaged in speaking lessons with gamification apps. One of the prime characteristics of the game is challenging. As stated by Joey and Jessica (2012), gamification allows learners to play around with rules, emotions, and social roles. When children play games, they are eager to compete and win the games. For most young learners, they may put $100 \%$ effort into achieving good results. Consequently, learners pay more attention in order to understand the lessons.

Furthermore, gamification apps are not only useful in increasing students' attention, but also beneficial in introducing and presenting parts of language, specifically vocabulary and grammatical structures. From Table 
DOI: $\underline{10.51386 / 25815946 / \mathrm{ijsms}-\mathrm{v} 4 \mathrm{i} 5 \mathrm{p} 108}$

Volume: 4 Issue: 5

September to October 2021

https://www.ijssmsjournal.org

4.4, there were around $47.8 \%$ of participants agreeing alongside $30.4 \%$ strongly agreeing with the use of gamification apps for introducing and teaching new words or grammatical structures. These results repeat the results of Fithriani (2021), Karatekin (2017) and Boyinbode (2018). These authors approved that gamification is a great supportive tool in helping students to considerably improve student English vocabulary abilities and there is no convincing reason not to use gamification apps.

The third highest percentage was for the perception of using gamification apps to introduce a speaking topic (60.9\% of participants agreed and $26.1 \%$ strongly disagreed). If used at the first stage of the lessons, gamification may be able to elicit learners to predict the main content they are going to learn. Lesson or topic introduction is an activity made by teachers in the early stage of the lesson to raise students' awareness and help them to have an overview of the lesson. However, it seemed not to have any prior research studied about speaking topic introduction and the use of gamification apps. This result is also slightly different from a prior study of Reese (1999, cited in Sripramong, 2004) about teaching English through games. In this study, the author signified that one of the main purposes of the game in the first stage of the lesson is to activate learners' background knowledge. This idea was also identified in item 12 of the questionnaire but it received $39.1 \%$ of participants agreeing and $24.6 \%$ highly agreeing.

Through the interviews, it was apparent that all 5 participants recognized the significant benefits of using gamification apps at the early stage of the speaking class for EFL young learners. Firstly, some teachers described some key features of some gamification apps, which are one of the reasons why they can get students' interest.

- They provide rich, new and eye- catching wallpaper interfaces (Teacher 2).

- Gamification apps have more eye catching interface (Teacher 3).

In addition, these types of apps are supposed to provide lots of activities for introducing vocabulary. Teacher 1 and 2 reported:

- $\quad$ The application is a vocabulary flashcard, providing vocabulary with pictures and pronunciation of words (Teacher 1).

- It can help teach vocabulary very effectively because it has pictures and sounds (Teacher 2).

Therefore young learners could learn new words through images and listening to the pronunciation of the words. It could be suggested that in the "raising awareness" stage when teachers tried to catch students' attention into the speaking lesson, introducing vocabulary and structures was the most remarkable benefit that the teachers mentioned. This is the same as what was shown in the results of the questionnaire.

\subsubsection{Teachers' perceptions of the benefits of gamification apps in appropriation}

TABLE II

TEACHERS' PERCEPTION OF THE BENEFITS OF GAMIFICATION APPS IN APPROPRIATION STAGE

\begin{tabular}{|c|c|c|c|c|c|c|c|}
\hline & & & \multicolumn{5}{|c|}{ Scale } \\
\hline & & & 1 & 2 & 3 & 4 & 5 \\
\hline \multirow{2}{*}{$\begin{array}{l}\text { 2. I believe gamification apps provide a rich source of } \\
\text { chants and songs that helps my learners to listen and } \\
\text { remember the spoken structures. }\end{array}$} & & & 2 & 1 & 11 & 21 & 34 \\
\hline & & & $(2.9 \%)$ & $(1.4 \%)$ & $(15.9 \%)$ & $(30.4 \%)$ & $(49.3 \%)$ \\
\hline \multirow{2}{*}{$\begin{array}{l}\text { 5. I believe activities on gamification apps can have } \\
\text { young learners repeat spoken structures. }\end{array}$} & & & 1 & 1 & 8 & 36 & 23 \\
\hline & & & $(1.4 \%)$ & $(1.4 \%)$ & $(11.6 \%)$ & $(52.2 \%)$ & $(33.3 \%)$ \\
\hline
\end{tabular}




\section{DOI: $\underline{10.51386 / 25815946 / \mathrm{ijsms}-\mathrm{v} 4 \mathrm{i} 5 \mathrm{p} 108}$}

15. I believe gamification apps can consolidate vocabulary and spoken structures my learners learned in the pre stage.
$4.03 \quad .804$

$\begin{array}{llll}4 & 9 & 37 & 19\end{array}$

$(5.8 \%) \quad(13.0 \%) \quad(53.6 \%)$

$(27.5 \%)$

18. I believe gamification apps can help my learners write their ideas down in a brainstorming stage.

$3.74 \quad .869$
6

$(8.7 \%)$
19

$(27.5 \%)$
31

$(44.9 \%)$
13

$(18.8 \%)$
27. I believe tasks on gamification apps such as reading aloud or singing along helps my learners memorize vocabulary well.

30. I believe gamification apps create a more comfortable virtual environment for learners to practise speaking.

\section{$4.41 \quad .828$}

1

$$
\text { (1.4\%) }
$$

9

(13.0\%)

(27.5\%)

$(58.0 \%)$

4.10 .770
(11.6\%)
39

$(56.5 \%)$

(29.0\%)

34. I believe gamification apps can increase young learners' accuracy in speaking.

It can be seen from Table II that the mean scores of 7 items were in range from 3.74 to 4.41 . It could be drawn to a conclusion that teachers had an agreement from high to very high level on the benefits of gamification apps in the appropriation stage.

Of 7 items, the item $27(\mathrm{M}=4.41)$ was the most agreed upon (30.4\% of teachers agreeing and $49.3 \%$ of teachers highly agreeing). The item showed that gamification apps could provide young learners a variety of tasks such as reading aloud or singing a song...that enrich their vocabulary. Following that, items 2 and 5 mentioned sources such as chants, songs or activities offered by gamification apps to listen, remember and consolidate vocabulary and structures. On the other hand, item 18 which was about helping learners write down their ideas in the brainstorming stage had the lowest level of agreement with the mean score of 3.74 . In the appropriation stage, learners are exposed to controlled practice to absorb knowledge that they are introduced in the first stage.

The results contribute to the prior studies of Nikmah (2020) and Hashim (2019). According to Nikmah (2020), these apps could assist pupils in memorizing words. When they used these apps, they became happier, more competitive, and more excited. Additionally, Hashim stated that "it can be concluded that gamified-learning is effective in terms of grammar achievement" (2019). These two studied met the idea that students' motivation, emotion and learning attitude were improved through gamified learning.

Answering the question about the benefits of gamification apps in the appropriation stage, teachers showed a positive attitude towards these apps.

- The application is a little bit for review and consolidation (Teacher 1).

- I think the applications are fun so the children feel interested and can absorb the language better (Teacher 2).

- $\quad$ I will use gamification apps in order to review vocabulary and grammar (Teacher 3).

Here, gamification apps are somehow similar to traditional games for teaching vocabulary such as matching words, unscrambling words, matching pairs of word and picture, etc. They are more appealing and competitive, 


\section{DOI: $\underline{10.51386 / 25815946 / \mathrm{ijsms}-\mathrm{v} 4 \mathrm{i} 5 \mathrm{p} 108}$}

however, when they are played on the online apps. As some teachers mentioned above, gamification apps are colorful and have diverse interfaces or even beautiful background music. It is obvious that children are easily attracted to them, resulting in increasing students' motivation and outcomes.

However, there were still some distinct opinions about the effects of gamification apps in the appropriation stage.

- I Io not use the application during this period. I think the applications are only effective in the early stages of the lesson, such as introducing vocabulary and structures (Teacher 4).

- I think it depends on the application, not all applications can help children apply the structure (Teacher 5) They showed a lower frequency of using gamification apps. The main reason was that they got acquainted with traditional activities and they had a strong belief in their effects.

\subsubsection{Teachers' perceptions of the benefits of gamification apps in autonomy}

TABLE III

MEAN SCORES OF ALL ITEMS IN AUTONOMY STAGE

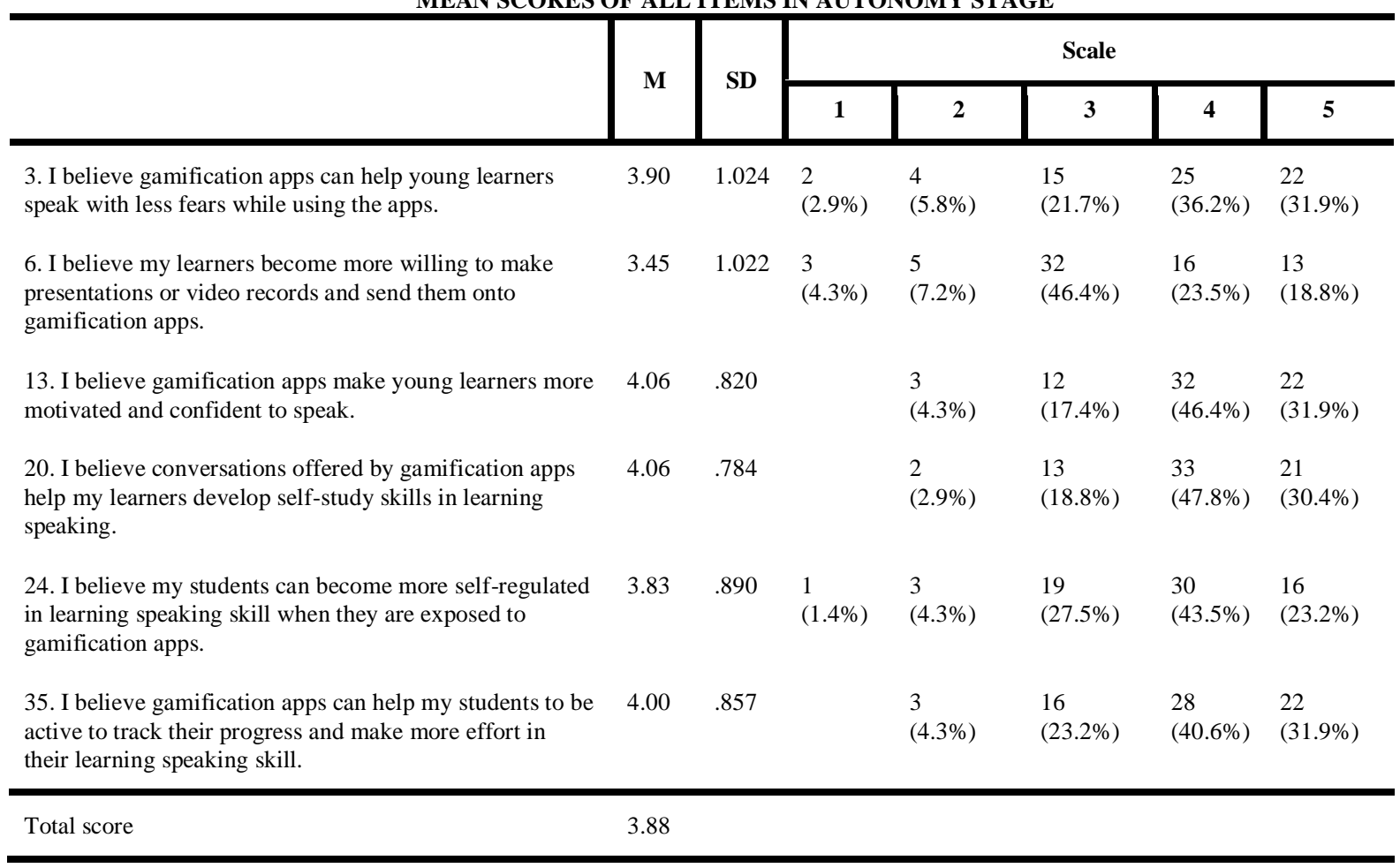

The "autonomy" minor group involved 6 items $(3,6,13,20,24,35)$. The benefits of gamification apps in this stage, as stated above, were less agreed by the teachers than the other 3 stages. However, as seen from Table 4.6, the mean scores of 6 items were from 3.45 to 4.06 which proved a high agreement in teachers' opinions of the benefits of gamification apps in learners' autonomy. Items 13, 20 received the highest agreement $(\mathrm{M}=4.06)$, followed by item $35(\mathrm{M}=4.00)$. Teachers believed that gamification apps had the ability to form learners' autonomy such as being more encouraged, confident to perform speeches, increasing self-study skill and being active to keep track of their learning. This finding resembles the results of (Pham, 2021) and Wu (2016). In the latest study of Pham (2021) about trigging learners' autonomy by using the combination of M-learning and Gamification, learners' academic performance and autonomy were believed to improve when teachers combined traditional lessons, M-learning and Gamification. The author said that gamification helps learners to "interact with other learners, track their progress, practice their skills and self-study at the same time" (Pham, 2021). Moreover, gamification can enhance learners' self-directed motivation and enable them to feel excited during the cognitive absorption process" (Wu, 2016). Autonomy is important in the learning process. Learners in this stage go beyond the practiced control to more autonomous activities such as the improvement of self-study skills, a self- awareness of learning outcomes or an increasing confidence. Therefore, it is the teachers that should aid their young learners in developing their own autonomy. 


\section{DOI: $\underline{10.51386 / 25815946 / \mathrm{ijsms}-\mathrm{v} 4 \mathrm{i} 5 \mathrm{p} 108}$}

Volume: 4 Issue: 5

In contrast to the questionnaire, most participants were less likely to use gamification in the autonomy stage. In terms of the benefits of gamification apps in students' autonomy in speaking class, teacher 1 and 2 respectively stated:

I cannot see a lot of the benefits of the apps in increasing fluency much. However, I found that they are somehow more confident and care about their grades (Teacher 1).

I don't really see the effectiveness of the apps in this period, even I don't use apps during this period, but replace them with other speaking activities. (Teacher 2).

I do not use the application during this period. I think the applications are only effective in the early stages of the lesson (Teacher 4)

Forming students' autonomy is not a simple process. It requires more time and more effort from both teachers and students. Therefore, gamification apps cannot interfere much in this period. Instead, teachers design more direct and traditional activities to help their young learners be exposed to language such as presentation or role play which cannot be conducted on these apps. However, there are some apps which are like virtual classrooms or social media so that students can post their work such as video or records onto these apps. In spite of their novelty, some teachers tended to try out new teaching materials to aid their students in this stage.

- I often give assignments to my learners to help them improve their self-study skill. Besides, I also use Flipgrid to ask my students to send their speaking video onto Flipgrid. This activity, I think, can help to boost my learners' confidence. (Teacher 3)

- I think my students can increase their self-study ability because these apps can be used both at home and in class (Teacher 5)

\subsubsection{Teachers' perceptions of the benefits of gamification apps in feedback}

TABLE IV

MEAN SCORES OF ALL ITEMS IN FEEDBACK STAGE

\begin{tabular}{l|l}
\hline & \\
\hline
\end{tabular}

3. I believe gamification apps can help young learners speak with less fears while using the apps.

3.90

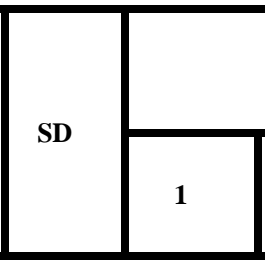

(2.

$2.9 \%)$

$(5.8 \%)$

15

Scale

\begin{tabular}{ll|l|l}
3 & 4 & 5 \\
\hline
\end{tabular}
more motivated and confident to speak.
6. I believe my learners become more willing to make presentations or video records and send them onto gamification apps.

13. I believe gamification apps make young learners

20. I believe conversations offered by gamification apps help my learners develop self-study skills in learning speaking.

$3.45 \quad 1.022$

$3 \quad 5 \quad 32$

$(4.3 \%)$

$$
(7.2 \%)
$$

$(46.4 \%)$

$4.06 \quad .820$

3

$$
12
$$

32

22

$$
(4.3 \%)
$$

$(46.4 \%)$

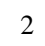

13

33

21

$(2.9 \%) \quad(18.8 \%) \quad(47.8 \%)$

$(30.4 \%)$

24. I believe my students can become more self3.83 .890 1 3

19

30

16 
DOI: $\underline{10.51386 / 25815946 / \mathrm{ijsms}-\mathrm{v} 4 \mathrm{i} 5 \mathrm{p} 108}$

Volume: 4 Issue: 5

September to October 2021

https://www.ijssmsjournal.org

exposed to gamification apps.

$(1.4 \%)$

$(4.3 \%)$

$(27.5 \%)$

$(43.5 \%)$

$(23.2 \%)$

35. I believe gamification apps can help my students to be active to track their progress and make more effort in their learning speaking skill.

$4.00 \quad .857$

3

16

28

22

in their learning

Total score

3.88

For this minor group, the researcher mentioned 7 items, including 8, 11, 14, 21, 26, 28 and 32. In the last subdivision of cluster 1, Descriptive statistics and Frequencies tests were also operated to check the level of teachers' agreement on the benefits of gamification apps in learning's feedback. Table 4.7 showed its results.

It can be seen obviously from table 4.7 that the mean scores of the items ranged between 3.78 and 4.35 . The results indicated that teachers had a positive and high agreement on the benefits of gamification apps in teaching speaking skill to young learners. Most teachers thought that gamification apps could help the feedback to become more interesting (33.3\% participants agreeing and $52.2 \%$ highly agreeing).

The game elements (rewards, badges, leaderboards...) can give users (young learners) an exciting experience, they may forget they are learning. However, there are also a lot of debates about the effectiveness of these game elements in learners' engagement. The studies of Huang \& Hew (2015), Barata et.al (2013) approved the positive effects of game elements on learners' engagement, whereas Deci et al. (2001); Lepper et al.(1973); Tang \& Hall, (1995) (cited in Hanus \& Fox, 2015) indicated that these game mechanics can harms motivation or even learning outcomes. In fact, up to now, there was insufficient data to indicate that using badges will increase student engagement or learning effectiveness. Consequently, teachers should combine traditional assessing methods and game elements in order to avoid the overuse resulting in negative effects on learning outcome.

Besides, teachers believed they could use some gamification apps to give comments or feedback for their learners' speaking videos $(60.9 \%$ of agreement and $24.0 \%$ of high agreement). On the other hand, not many teachers identified the benefits of gamification apps in creating peer correction. In fact, gamification apps tended to be more interactive and sociable. Learners could receive feedback or comments not only from teachers but also from their friends. However, the results of the research suggested that this benefit was ignored or less care compared to other elements.

When it comes to speaking feedback, most teachers did not or realize just a little the benefits of these types of apps. Some teachers suggested:

-I usually give direct feedback, not using scoring software much (Teacher 4).

- $\quad$ Teachers are more likely to give grades on direct tests.(Teacher 5)

However, there were also teachers who took advantage of gamification apps to check learners' receptiveness after a class or give bonus or rewards.

- $\quad$ There will be rewards and rankings. I will know which students are learning well or not well. (Teach 2).

- I use Quizizz to design multiple-choice questions to check the children's receptivity level (Teacher 3).

\subsection{Teachers' perceptions of the challenges of using gamification apps to teach speaking skill to EFL young learners}

In spite of the fact that teachers highly agreed about the benefits of gamification apps in use, there were some challenges that should be considered. As a result of it, cluster 2 was then analyzed to explore how teachers thought about these obstacles.

\subsubsection{Teachers' perceptions of the challenges of using gamification apps caused by external factors}

Descriptive statistics tests were next carried out to find the mean scores of the challenges of gamification apps, external factors and teacher-related factors. The results were shown in Table 4.9

Descriptive statistics and Frequencies tests were run to check the mean scores of 5 items of external factors. 
DOI: $\underline{10.51386 / 25815946 / \mathrm{ijsms}-\mathrm{v} 4 \mathrm{i} 5 \mathrm{p} 108}$

Volume: 4 Issue: 5

September to October 2021

https://www.ijssmsjournal.org

TABLE $V$

MEAN SCORES OF 5 ITEMS OF EXTERNAL FACTORS

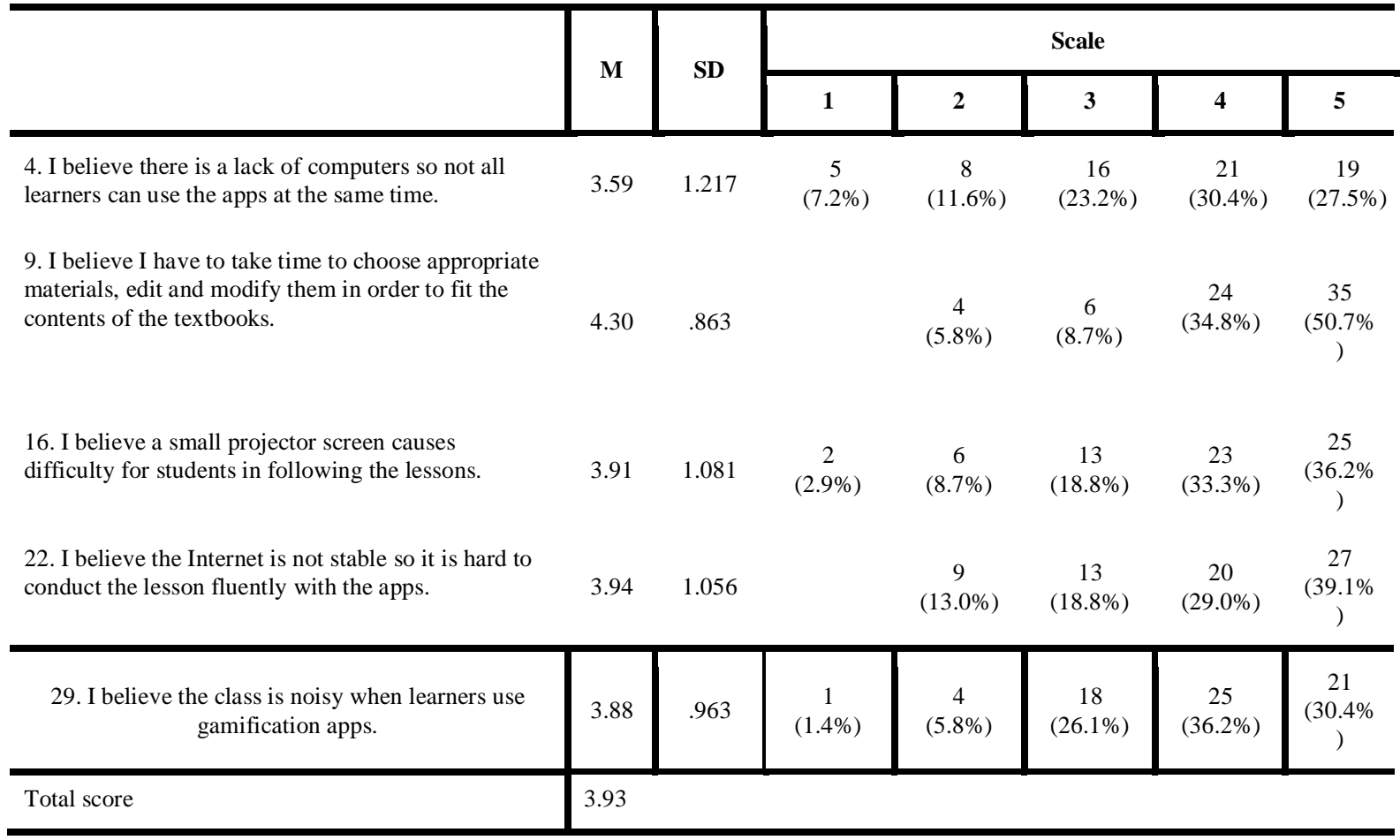

Table $\mathrm{V}$ presented clearly the mean scores of 5 items were in range from 3.59 to 4.30 . It can be recognized that teachers' agreement on external factors in using gamification apps in their speaking teaching to young learners were at a high level. In specific, they most agreed that it took their time to edit and compose content onto these gamification apps because the available content on these apps was not the one in their syllabus (Item 9; M=4.30), with $85.5 \%$ of participants agreeing. Following that, $68.1 \%$ of teachers believed that an unstable Internet was also considered as the second biggest obstacle during their teaching process (Item 22, M=3.94). Most teachers disagreed with the statement about the lack of computers or other technical devices for young learners to use (Item 4, M=3.59). These results concur with the study of Atmojo (2020) about challenges when learning online and using technology. Learners are not always on a good Internet connection. Unstable Internet can demotivate learners and make them more passive in the classroom. However, the idea about no lack of computers or technical devices is different from this study. Some students have poor conditions and they cannot own any technical devices. Therefore, they cannot approach online learning and gamified classrooms.

Some teachers agreed that using these apps were rather time consuming. The main reason was that a few children had not gotten used to manipulating the apps so teachers often had to spend time instructing them.

- Not all children can operate effectively (Teacher 1).

- I I find it quite time consuming due to the children's manipulation (Teacher 2).

- Due to the children's devices and manipulations, some children could not access the application. (Teacher 2).

Although teachers supported students and their parents with instructions to use gamification apps beforehand, students' manipulation on them often failed.

In addition, unreliable Internet connection is also another reason for wasting time. This resembles the result of the questionnaire

- The Internet connection, so I cannot guarantee that the children can simultaneously access the application (Teacher 2).

- I think it's an Internet problem, not every child has a strong network connection, so learning and participating in activities are often interrupted (Teacher 4). 


\section{DOI: $\underline{10.51386 / 25815946 / \mathrm{ijsms}-\mathrm{v} 4 \mathrm{i} 5 \mathrm{p} 108}$}

Volume: 4 Issue: 5

September to October 2021

https://www.ijssmsjournal.org

Gamification apps are online tools so technical devices alongside the Internet play an inevitable part of this learning method. However, not all students have a stable Internet to participate in activities in the class. Sometimes, the interruption of the Internet can reduce students' motivation and interest.

Furthermore, it was recognized by some teachers that gamification apps were attractive and colorful that might distract young learners. These young learners tended to prefer playing than learning so they were sometimes eager to be able to play games and less concentrated in other activities. As a result, the effectiveness of lessons could diminish compared to what teachers expected.

- $\quad$ Some children are too interested in the game part and are addicted and distracted from learning a bit (Teacher 1).

- $\quad$ Children often lose focus and love games more (Teacher 4).

4.2.2 Teachers' perceptions of the challenges of using gamification apps caused by teacher-related factors Similarly, Descriptive statistics and Frequencies tests were run to examine the mean scores of individual items.

TABLE VI

MEAN SCORES OF 5 ITEMS OF TEACHER-RELATED GROUP

\begin{tabular}{|c|c|c|c|c|c|c|c|}
\hline & \multirow{2}{*}{$\mathbf{M}$} & \multirow{2}{*}{$\begin{array}{l}\text { S } \\
\text { D }\end{array}$} & \multicolumn{3}{|c|}{ SCALE } & & \\
\hline & & & $\mathbf{1}$ & 2 & 3 & 4 & 5 \\
\hline $\begin{array}{l}\text { 10. I believe some gamification apps are hard and } \\
\text { confusing for me to use. }\end{array}$ & 3.59 & .975 & $\begin{array}{c}2 \\
(2.9 \%)\end{array}$ & $\begin{array}{c}7 \\
(10.1 \%)\end{array}$ & $\begin{array}{c}19 \\
(27.5 \%)\end{array}$ & $\begin{array}{c}30 \\
(43.5 \%)\end{array}$ & $\begin{array}{c}11 \\
(15.9 \%)\end{array}$ \\
\hline $\begin{array}{l}\text { 17. I believe my manipulation on computers is not } \\
\text { skilled enough to use smoothly in the class. }\end{array}$ & 2.80 & 1.119 & $\begin{array}{c}7 \\
(10.1 \% \\
)\end{array}$ & $\begin{array}{c}25 \\
(36.2 \%)\end{array}$ & $\begin{array}{c}17 \\
(24.6 \%)\end{array}$ & $\begin{array}{c}15 \\
(21.7 \%)\end{array}$ & $\begin{array}{l}5 \\
(7.2 \%)\end{array}$ \\
\hline $\begin{array}{l}\text { 23. I believe I might be nervous and unconfident } \\
\text { when using gamification apps in front of the class. }\end{array}$ & 2.99 & 1.169 & $\begin{array}{c}9 \\
(13.0 \% \\
)\end{array}$ & $\begin{array}{c}13 \\
(18.8 \%)\end{array}$ & $\begin{array}{c}24 \\
(34.8 \%)\end{array}$ & $\begin{array}{c}16 \\
(23.2 \%)\end{array}$ & $\begin{array}{c}7 \\
(10.1 \%)\end{array}$ \\
\hline $\begin{array}{l}\text { 36. I believe I cannot manage the class resulting in } \\
\text { student's disinterest and distraction. }\end{array}$ & 2.87 & 1.162 & $\begin{array}{c}6 \\
(8.7 \%)\end{array}$ & $\begin{array}{c}27 \\
(39.1 \%)\end{array}$ & $\begin{array}{c}12 \\
(17.4 \%)\end{array}$ & $\begin{array}{c}18 \\
(26.1 \%)\end{array}$ & $\begin{array}{c}6 \\
(8.7 \%)\end{array}$ \\
\hline 37. I believe I may fail to manage time in the class. & 2.54 & 1.092 & $\begin{array}{c}13 \\
(18.8 \% \\
)\end{array}$ & $\begin{array}{c}22 \\
(31.9 \%)\end{array}$ & $\begin{array}{c}21 \\
(30.4 \%)\end{array}$ & $\begin{array}{c}10 \\
(14.5 \%)\end{array}$ & $\begin{array}{c}3 \\
(4.3 \%)\end{array}$ \\
\hline Total score & 2.96 & & & & & & \\
\hline
\end{tabular}

It is apparent from the table that teachers' perception of teacher-related factors was neutral (M=2.96). This explained that teachers did not totally agree with the teacher-related aspect that raised the challenges of using gamification apps. Approximately $59.4 \%$ of participants thought gamification apps were confusing and complex to use, while for the other aspects, not over $50 \%$ agreed with them. This finding was aligned with the study of Sánchez Mena \& Martí Parreño (2017). The authors mentioned some challenges teachers may meet were: (1) time to prepare gamified activities, (2) lack of knowledge on gamification, and (3) inappropriate classroom setting. Gamification apps are not completely new or novel. They are deployed a great deal in many social fields including medicine, technology or even education. However, in order to use and operate fluently, teachers should spend time preparing before the classroom. 
DOI: $\underline{10.51386 / 25815946 / \mathrm{ijsms}-\mathrm{v} 4 \mathrm{i} 5 \mathrm{p} 108}$

Volume: 4 Issue: 5

September to October 2021

https://www.ijssmsjournal.org

The factors associated with teachers were less likely to be mentioned by the teachers. They said that they had some main problems with classroom management and editing the contents on the apps.

- Some children are interested in games and make class noisy, teachers need time to settle down (Teacher 2).

- $\quad$ The class may be noisy, due to the children's questions and equipment or Internet errors (Teacher 5).

- The suggested content on the application does not match the content of my syllabus, so I have to completely compose it. (Teacher 3)

- It takes me a bit of time to edit. (Teacher 4)

- $\quad$ Some applications take time to prepare (Teacher 5)

-

The data from the interview showed that when getting young learners to play games, it was hard for the teachers to operate and manage their class at the same time. There were always unexpected things happening during the class. On the other hand, most of them felt pretty confident with their manipulation on gamification apps because the majority of apps' interfaces were simple to utilize and operate.

Nevertheless, this result was in contrast to the one in quantitative analysis. The results from the questionnaire suggested that teachers were a bit confused when using gamification apps in their teaching. Gamification apps are not really a new tool in this era. It is clear that they are used in many fields in life including technology and education, yet users need time to get used to them. Specifically, for teachers they should prepare carefully, try them out and rehearse before the class so that they can never interrupt the teachers. There is one participant stating that:

- I am familiar with the applications, plus the interface is easy to use, so I have no difficulty in using it (Teacher 4).

- I do not have much difficulty, some applications take time to prepare, but teachers can flexibly replace other activities to save more time (Teacher5).

\subsection{Pedagogical implication}

\section{IMPLICATIONS AND CONCLUSION}

The benefits and limitations of gamifying applications should be addressed when selecting appropriate speech instruction exercises for young learners after learning about them. Although it appears that gamification is not entirely new, it is still not widely used by teachers in the Vietnamese setting. Exploring and exploiting up-todate didactic resources is critical in the unpleasant conditions of a pandemic, such as now, when teaching and learning are relocated to the Internet, so that teaching English can meet a need and the efficacy of education may be increased. At the moment, mixed methods are seen to be beneficial. Teachers can continue to bring value to traditional activities while also incorporating cutting-edge technological resources to revitalize lessons and increase learners' motivation and outcomes.

Furthermore, both teachers and students require time to become accustomed to gamification software. Teachers can actively participate in teacher communities or seminars to stay up to speed on what is going on in this period. Furthermore, they must devote time to researching and using technology in order to stay up with educational innovation. Learners require parental assistance to become comfortable with utilizing technology. However, maintaining a good attitude and a strong desire to study can help individuals overcome these hurdles.

Finally, educational institution administrators have started using technology into teaching and learning. Professional training courses, on the other hand, are required for instructors to stay up with new teaching materials and abilities. These seminars, workshops, classroom observations, and teacher conversations are beneficial to instructors since it is thought that professional development is always helpful in the teaching journey. Teachers may feel more confident and comfortable when confronted with changes from the 4.0 age as a result of updated knowledge.

\subsection{Limitations of the study}

The first constraint of this study is that it consisted of a small sample size of participants. The number of respondents was 69 teachers who are teaching young learners at some language centers in Can Tho. They all participated in responding to the questionnaire. None of them took part in piloting the questionnaire beforehand. 


\section{DOI: $\underline{10.51386 / 25815946 / \mathrm{ijsms}-\mathrm{v} 4 \mathrm{i} 5 \mathrm{p} 108}$}

Six of them were invited randomly into the interview. As a result, such a small number of participants may not be representative for the whole participants. Secondly, the research was conducted only in some language centers in Can Tho city. Therefore, it cannot be taken into account for the whole language centers or schools in Viet Nam. Besides, lack of classroom observations is another inconvenience for this research. The results in this research solely rely on teachers' opinions. It would be better if the researcher could have observations to have a closer look into teaching practice. However, the results of this research are expected to have some useful aspects for teachers, students, students' parents and administrators of language centers.

\subsection{Recommendations for further research}

From the limitations mentioned above, there are some suggestions for further studies. The studies should involve a larger sample size of participants. Additionally, it should be considered to expand the scope of the study to gather more responses. The study can move further from language centers to public schools to have the whole perspective of the issue. Finally, the combination of different methodologies such as questionnaire, survey, classroom observations should be taken into account.

\section{ABOUT THE AUTHORS}

Nguyen Thi Thanh Thuy is an English teacher at a language center in Can tho city, Vietnam. She completed a Bachelor ${ }^{e e}$ s degree in English in Education in 2018. She is currently an MA student at Can Tho University. She is fond of researching 4 English skills and teaching methodology.

Luu Nguyen Quoc Hung is a director of Centre for Foreign Languages, Can Tho University. His research interests include English language teaching and learning, cross cultures and professional development.

\section{REFERENCES}

[1] J. Martí-Parreño, E. Méndez-Ibáñez \& A. Alonso-Arroyo. (2016). The Use of Gamification in Education: a Bibliometric and Text Mining Analysis. Journal of Computer- Assisted Learning, 32(6), 663- 676. doi: 10.1111/jcal.1216.

[2] Yildirim, L. (2017). The Effects of Gamification-based Teaching Practices on Student Achievement and Students' Attitudes toward Lessons. The Internet and Higher education, 33, 86-92. doi:10.1016/j.iheduc.2017.02.002.

[3] Petkov P, Köbler F, Foth M, Medland RC, Krcmar H (2011) Engaging energy saving through motivation-specific social comparison. In: Proc conference on human factors in computing systems, Vancouver, pp 1-6

[4] Tan Ai Lin, D., Ganapathy, M., \& Kaur, M. (2018). Kahoot! It: Gamification in Higher Education. Pertanika Journal of Social Sciences \& Humanities, 26(1).

[5] Landers, L. N. (2014). Developing a Theory of Gamified Learning: Linking Serious Games and Gamification of Learning, 45(6), 752-768. doi:10.1177/1046878114563660.

[6] Garris, R., Ahlers, R., \& Driskell, J. E. (2002). Games, motivation, and learning: A research and practice model. Simulation \& gaming, 33(4), 441-467.S. Tobias, J. Fletcher, D. Y. Dai et A. P. Wind, «Review of research on computer games,» Computer games and instruction, vol. 127, p. 222, 2011.

[7] Tobias, S., Fletcher, J. D., Dai, D. Y., \& Wind, A. P. (2011). Review of research on computer games.

[8] Burns, A. (2012). A holistic approach to teaching speaking in the language classroom. In Symposium (pp. 165-178).

[9] Bunchball, Inc. (2010). Gamification 101: An introduction to the use of game dynamics to influence behavior.

[10] Retrieved from http://www.bunchball.com/sites/default/files/downloads/gamification101.pdf

[11] Brown, G. and G. Yule. (1983). Teaching the Spoken Language. Cambridge: Cambridge University Press.

[12] Bohari, L. (2020). Improving speaking skills through small group discussion at eleventh grade students of SMA Plus Munirul Arifin NW Praya. Journal of Languages and Language Teaching, 7(1), 68-81.

[13] Larsen-Freeman, D. (2001). Teaching grammar. Teaching English as a second or foreign language, 3, 251-266.

[14] Nunan, D. (1998). Teaching grammar in context

[15] Hedge, T. (2000). Teaching and learning in the language classroom. Oxford: Oxford University Press. http://www.educause.edu/library/resources/7-things-you-should-know-about-gamification 


\section{DOI: $\underline{10.51386 / 25815946 / \mathrm{ijsms}-\mathrm{v} 4 \mathrm{i} 5 \mathrm{p} 108}$}

Volume: 4 Issue: 5

[16] Ken Lackman. 2010. Teaching speaking sub-skills: Activities for improving speaking. Toronto, Canada: Lackman \& Associates.

[17] Thornbury, S. (2005). How to teach speaking. Longman.

[18] The United Nations Convention on the Rights of the Child. 1990. Available at http://www.unicef. org.uk/Documents/Publicationpdfs/UNCRC_PRESS200910web.pdf (accessed on 22 July 2013).

[19] Rixon, Shelagh.1999. Young learners of English: some research perspectives. London: Longman.

[20] Pinter, A. (2006). Teaching young language learners. Oxford: Oxford University Press

[21] Brewster, J., Ellis, G. \& Girard, D. (2011). The primary English teacher's guide (New Edition). Essex: Penguin English Guides.

[22] Arıkan, A., \& Taraf, H. U. (2010). Contextualizing young learners' English lessons with cartoons: Focus on grammar and vocabulary. Procedia-Social and Behavioral Sciences, 2(2), 5212-5215.

[23] Cameron, L. (2001). Teaching languages to young learners. Cambridge: Cambridge University Press.

[24] Halliwell, S. (1992). Teaching English in the primary classroom. New York: Longman.

[25] Fithriani, R. (2021). The Utilization of mobile-assisted gamification for vocabulary learning: Its efficacy and perceived benefits. Computer Assisted Language Learning Electronic Journal (CALL-EJ), 22(3), 146-163.

[26] Karatekin, İ. (2017). The use of gamification in teaching foreign language vocabulary for beginners (Master's thesis, Çă̆ Üniver sitesi Sosyal Bilimler Enstitüsü)

[27] Boyinbode, O. (2018). Development of a gamification based English vocabulary mobile learning system. International Journal of Computer Science and Mobile Computing, 7(8), 183-191.

[28] Sripramong, S. ( 2004). "The Study of the Effect of Using Vocabulary Games on the Retention in Learning Vocabulary of Prathomsuksa Five Students.” Unpublished master' thesis. Srinakharinwirot University. Thailand.

[29] Nikmah, H. (2020). Gamification to Improve Students' Engagement in Learning English. Proceeding of 1stConference of English Language and Literature (CELL), 2(1), 60-70.

[30] Huang, J. L., Liu, M., \& Bowling, N. A. (2015). Insufficient effort responding: Examining an insidious confound in survey data. Journal of Applied Psychology, 100, 828-845.

[31] Hanus, M. D., \& Fox, J. (2015). Assessing the effects of gamification in the classroom: A longitudinal study on intrinsic motivation, social comparison, satisfaction, effort, and academic performance. Computers \& education, 80, 152-161 